\title{
9 \\ Informal Life Politics of Marketisation in North Korea
}

\author{
Eun Jeong Soh
}

\section{Introduction}

Observers of today's North Korea recognise that marketisation is a widespread phenomenon there. While the state-planned economic sector continues to persist, changsa ${ }^{1}$ (a general term referring to various types of trade and business activities, on a private economic level) has become a necessity for survival. One's capacity to engage in trade activities has become a determinant of the survival and wealth of the household. Market as a mechanism of exchange is still limited to goods and services, and monetary and financial markets do not yet exist on a significant scale. ${ }^{2}$ Nevertheless, in the everyday life of North Koreans, trade, both in marketplaces and in the underground economy, has become an absolutely crucial and fundamental means for survival and livelihood. The significance of the market not only holds for ordinary North Koreans but also for state officials at all levels, as well as for the

1 Lankov and Kim (2008) define changsa as 'dealings in the marketplace'. But in fact, changsa in North Korea also includes long-distance bartering and selling of goods outside of the marketplace: Andrei Lankov and Kim Seok-hyang, 'North Korean Market Vendors: The Rise of Grassroots Capitalists in a Post-Stalinist Society', Pacific Affairs 81-1 (2008): 53-72.

2 Lee Suk-ki, 'Change and Prospect for North Korea's Market', Unification Media Group Conference (14 September 2015), www.youtube.com/watch?v=uhVroKIUo88. 
maintenance of public institutions and enterprises. ${ }^{3}$ The market has become an essential backbone for the life of individual households as well as the entire North Korean political and economic system and thus has the potential to cause the current long-lasting regime either to fall, to muddle through, to transform, or even to thrive.

What is puzzling about the spread of changsa and the resultant marketisation of goods and services in North Korea is that they occurred in the absence of decisive and consistent institutional reforms necessary to facilitate marketisation. Marketisation in North Korea took place under the continued presence of state suppression of basic freedom of movement and association and the absence of property rights. ${ }^{4}$ How have North Koreans continued to expand their private economic activities despite state authorities' persistent social controls and the selective punishments of market traders carried out in an effort to inhibit private economic activities? What social mechanisms have enabled such a formation and expansion of marketisation from below without the presence of marketinducing or market-permitting reforms?

On the phenomenon of marketisation in North Korea, Haggard and Noland most notably distinguish North Korea's form of marketisation as a 'marketisation from below'. Whereas other cases of marketisation occurred, initiated through top-down policy responses resulting from a bargaining process among elites, changes from below dominated the North Korean process and pushed the state to make incremental concessions. Marketisation in North Korea was 'a by-product of state failure', actualised by the decline of the state socialist economy in general and a more acute absence of wages and rations, which led to the full-blown famine of the 1990s. ${ }^{5}$ Despite the central Party's efforts to crack down on market forces, state officials' corruption and exploitation of office for private gain facilitated the spiralling growth of markets. ${ }^{6}$

3 Kim Young-hwan, 'Change and Prospect for North Korea's Market', Unification Media Group Conference (14 September 2015), www.youtube.com/watch?v=Xq1SJ5nhTh0.

4 On this, see editor's remark on Andrei Lankov, 'The Limits to Marketisation: State and Private in Kimist North Korea', (14 June 2013), Sino-NK, sinonk.com/2013/06/14/marketization-and-itslimits-state-private-enterprises-in-north-korea/.

5 Haggard and Noland, 'Reform from Below: Behavioral and Institutional Change in North Korea', Journal of Economic Behavior and Organization 83 (2010): 133-4.

6 ibid., 133. 
But seeing marketisation in North Korea simply as a phenomenon of state failure devalues the agency of people driven by a desire for survival. Was the private response to state failure indeed 'unintended'?7 This conceptualisation overlooks the presence of tight state controls on freedom of movement and information and organised social life, despite which marketisation in North Korea occurred. Multiple agencies including the Public Security Bureau, the police, the Army and other ad hoc bodies created by the Centre implemented measures against anti-socialist activities including the market trade of various prohibited items. On top of these social control mechanisms, frequent ideological education and work mobilisation were supposed to divert people from fully engaging in private economic activities. In terms of policy inconsistencies, the central state swung between reluctant limited liberalisation measures in 2002 and counter-measures in 2005, followed by the disastrous currency reform in 2009. Given the state's efforts to deter and limit the growth of the market, grassroots marketisation in North Korea can more accurately be understood when the agency of individuals conducting market activities under such circumstances is taken into consideration in conjunction with the phenomenon of state failure. In fact, state failure, in the case of North Korea, did not simply occur from the top. Rather, people have helped to erode the state from below.

To highlight the dynamics of the process, this study pays attention to micro-dynamic mechanisms of the formation of collaborative relationships between law-implementing officials of the state apparatus and those who engage in trade. While distinguishing the two for analytical purposes, officials of the state apparatus, in reality, if not directly and openly, are most actively involved in trade. The relationship between the two is a dualistic one, cooperative as well as contentious. This chapter identifies practical strategies, cultural factors and normative justifications that constitute this relationship and facilitate the marketisation process under control.

Due to practical limitations on observing everyday life in North Korea, the evidence presented in this chapter comes from narratives of refugee informants in South Korea. I conducted two rounds of interviews-the first round from October to December 2013 and the second round from April to June 2015. Each round consisted of 25 interviews, in which 
interviewees spoke about their own experiences and observation of private economic activities in North Korea. The refugee informants came from a diverse range of backgrounds in terms of age, gender, hometown, occupation, and the year of defection. Inevitably, however, the pool of refugee informants who participated in this study may not be representative of the population in North Korea as a whole. The majority of informants were women and come from North Hamkyung and Ryanggang provinces, where marketisation began and spread most extensively. Therefore, allowance must be made for possible regional and gender biases in the material presented here.

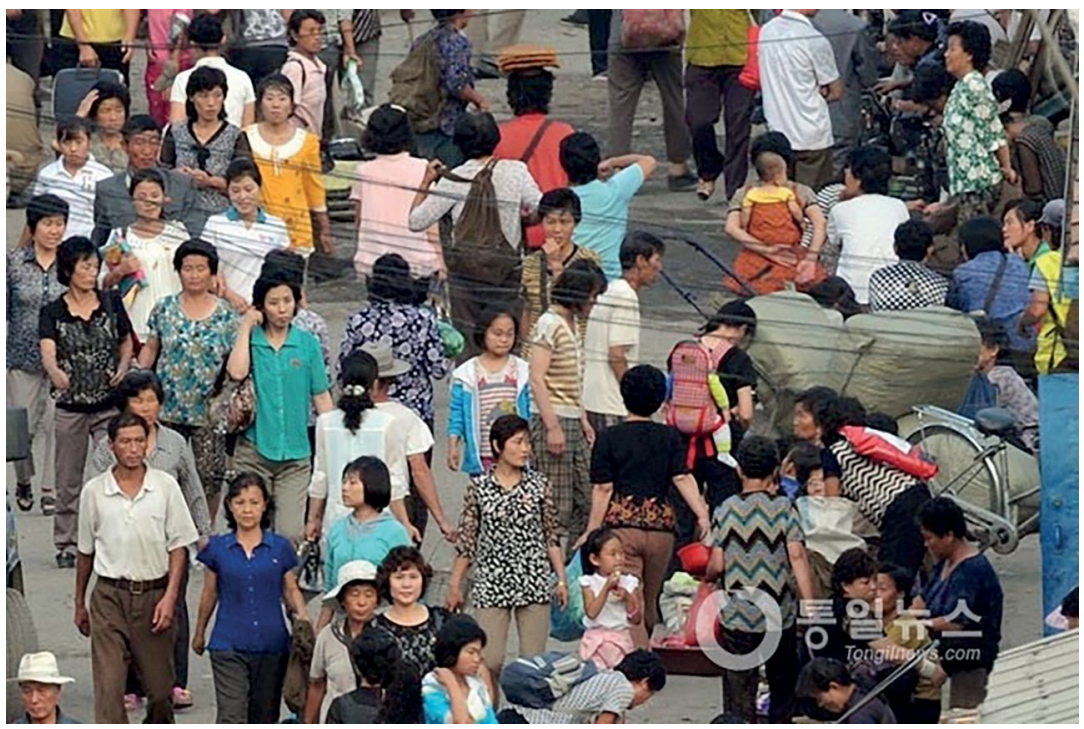

Figure 12: Hyesan Market, 22 July 2015.

Source: Courtesy of Cho Chun-hyun.

\section{Background: Conducting Private Economic Activities under Collectivism in North Korea}

The single most important feature of life in North Korea is the high degree of collectivism. North Koreanists have utilised a range of political science concepts to characterise the North Korean state. The state is often defined as being highly personalistic due to the supreme importance 
of the leader, ${ }^{8}$ and totalitarian due to the extent of the state control of the society through ideology and organisation. It is also often seen, on the one hand, as a corporatist organic entity and, on the other, as neoConfucian in its uniquely East Asian features where the family serves as a model of the state. The extent to which each of these characterisations is emphasised depends on the period of North Korea's history being examined. ${ }^{9}$ No one model correctly represents North Korea, but rather all emphasise various features that make the North Korean society uniquely collective. The deified leader, layers of bureaucracies and social organisations, extensive surveillance, the system of social stratification, and the unifying ideology of chuch'e (self-reliance) all facilitate, strengthen and reinforce collective ways of life in North Korea.

Scholars describe North Korea as one of the most intensely organised societies in the world and in history. ${ }^{10}$ This collectivism was fostered initially through its efforts to restructure society in the postcolonial period of socialist revolution from 1945, leading up to the founding of the government in 1948. ${ }^{11}$ Suzy Kim's recent book, Everyday life in the North Korean Revolution, 1945-1950, describes the experience of the North Korean Revolution (1945-50) as the realisation of a socialist modernity shared with its Chinese and Soviet neighbours, but unique in its exceptionally high level of mobilisation in everyday life spaces. ${ }^{12}$ It was understood that the well-being of the individual was achieved only through the well-being of the collective. The collectivism of North Korean society strengthened after the Korean War with Kim Il-Sung's consolidation of his unitary power by eliminating all countervailing factions. Collectivism as envisioned in North Korea was an imaginary wartime solidarity against powerful external enemies that Wada Haruki calls a guerrilla state. ${ }^{13}$

$8 \quad$ Linz and Stepan briefly mention North Korea as an extreme form of the patrimonialism defined by Max Weber: Juan J. Linz and Alfred Stepan, Problems of Democratic Transition and Consolidation: Southern Europe, South America, and Post-Communist Europe (Baltimore and London: The Johns Hopkins University Press), 51-2.

9 Charles K. Armstrong, 'The Nature, Origins, and Development of the North Korean State', in Samuel S. Kim ed., The North Korean System in the Post-Kim Il Sung Era (New York: Palgrave, 2001), 39-64.

10 Michael E. Robinson, Korea's Twentieth-Century Odyssey: A Short History (Honolulu: University of Hawai'i Press, 2007), 150.

11 ibid.

12 Suzy Kim, Everyday Life in the North Korean Revolution, 1945-1950 (Ithaca and London: Cornell University Press, 2013), Kindle Version, 2257(7410).

13 On the use of the term 'guerrilla state', see Armstrong, 'The Nature, Origins, and Development of the North Korean State', 23-4. 
Collectivism continued to be a foundation for the country's postwar recovery and socialist construction based on mass mobilisation campaigns. Most representatively, the Chollima movement initiated in 1958 resembled the Soviet Union's Stakhanovite movement and was also influenced by the Chinese Great Leap Forward. Mass mobilisation campaigns, along with aid from Chinese and Soviet allies, achieved a decade of initial success. Bruce Cumings notes Immanuel Wallerstein's regard for North Korea (the Democratic People's Republic of Korea, DPRK) as a model for the periphery: 'The DPRK shows the way in the periphery ... it never idled but always raced'. ${ }^{14}$

Life in the workplace, social organisations, and neighbourhood units were at the core of everyday life in North Korea. Every individual belonged to groups of youths, workers, women and peasants. The percentage of the population who are members of the state Party was higher in North Korea than in any other communist state in the 1980s. ${ }^{15}$ Organisational life was value-ridden: recognition and advancement in the Party and related political structures was considered more precious than material gains. As one North Korean defector scholar humorously puts it, 'we were closer to our work colleagues than to our husband'. ${ }^{16}$ In this everyday collective life, people lived simple, hardworking lives and felt generally content and secure about their livelihoods. A level of shortage existed in households under the state rations system but relative egalitarianism prevented the fear that is caused by a sense of relative deprivation. Cumings notes that the success of the leadership in cultivating communal collective life was the most striking thing about North Korea to Americans. A British diplomat described North Korea as 'one big kibbutz'. ${ }^{17}$

The tight culture of collectivism shaped by the North Korean state socialist revolution began to lose its almost total embrace of society with the decline of its state-planned economy. The North Korean economy was already showing signs of strain in the late 1970s. Shortage of consumer goods and deterioration in the quality and the quantity of food supplies

14 Wallerstein quoted in Bruce Cumings, 'Corporatism in North Korea', Journal of Korean Studies 4 (1983): 293.

15 Bruce Cumings, 'Corporatism in North Korea', 291-2.

16 Hyun In-ae, 'Pukhansahoe net'ŭwŏk'ŭ: sijang esŏui chuminsaenghwal' [Network in North Korean Society: Life of Residents in the Marketplace], paper presented at The 2015 Soongsil Institute for Peace and Unification Spring Seminar, Seoul, 22 May 2015, 27-46.

17 Andrew Holloway quoted in Bruce Cumings, Everyday Life in North Korea (New York and London: The New Press, 2004), 139-40. 
were already evident from the mid-1980s.$^{18}$ Households, especially those with many growing children, supplemented food through informal coping strategies. Seven hundred grams of grain per day for office workers, 800 grams per day for manual labourers, and 300 grams for children were never adequate. Households supplemented consumption of vegetables and protein by picking and gathering greens (namul) in the mountains, cultivating kitchen plots, and breeding pigs and rabbits at home to sell through informal networks to gain additional income. Elderly persons in rural areas cultivated additional plots of unused land to contribute to the household food supply. Andrei Lankov notes that private space in North Korea was much smaller than that in the Soviet Union. Nevertheless, these minuscule private spaces existed and became foundational and habitual bases for coping strategies in the 1990s. ${ }^{19}$

As much as North Korea's collectivisation experience demonstrated totality in the unity between state authority and the people, the people's demand for private economic spaces, as it grew in scale, inflicted significant and irreversible damage on the state authority's ability to exert control over its people. The demand occurred at the margins and at the bottom of society where women and elderly and labourers and farmers, out of sheer concern for survival of their households, resorted to various private economic activities as coping strategies despite knowing that such activities were transgressive of socialist ideals. The state's easing of the spaces for private market economic activities occurred reluctantly in response to the unsettling demands for space for market trade. The following three policies demonstrate that the state yielded to the growing grassroots demands for private economic activities even prior to the full-blown crisis that began in 1995 .

In the 1980s, government policies intended to co-opt informal and illegal economic activities resulted in the further opening up of spaces for private economic activities. In 1984, the state launched an 'August 3rd Movement' in an attempt to ameliorate the shortage of consumer goods that was apparent in the 1980s, by having factories and enterprises

18 Ch'oe Pong-dae and Ku Kap-u, 'Pukhan ŭi tosi 'changmadang' hwalsŏnghwa ŭi tonghak 1990nyŏndae sinŭiju, ch’ŏngjin, hyesan ŭl chungsimŭro' [Changes in Vitalization of Marketplace in North Korean Cities - With a Focus on the 1990s Sinuichu, Chongchin, and Hyesan], Hyŏntaepukhanyŏnku 8, no. 3 (2005).

19 Andrei Lankov, The Real North Korea: Life and Politics in the Failed Stalinist Utopia (Oxford: Oxford University Press, 2013), 36. 
source their own inputs to produce consumer goods. ${ }^{20}$ According to Choi and Koo, this was also a policy to ameliorate growing pilfering and illegal side work by factory workers who could not feed their family and obtain household necessities by relying solely on their wages and food rations. ${ }^{21}$ As the authorities allowed marketisation of some products to provide incentives for people to produce these goods and voluntarily supply them to the state, this resulted in the spread of markets. People demonstrated creativity. ${ }^{22}$ Home-manufactured products flowed into farmers' markets and invigorated market trade from the mid-1980s onwards. As a result, by 1999 , over 300 farmers' markets had been formed. ${ }^{23}$

Another policy was the resumption in 1984 of permission for ethnic Korean residents from China to visit family in the DPRK. ${ }^{24}$ Border trade between North Korea and China had existed in the 1940s, ceased during the 1970s, and was then revived after the normalisation of DPRK-China relations in 1982. Ethnic Korean petty traders brought in food and manufactured goods to their relatives residing in the border areas of North Korea. These goods were quietly sold to neighbours and acquaintances. They became an important source of consumer goods for residents of the border area and had a major influence on the lives of these people. Those who were exposed to the border trade in the earlier period became 'early birds' in trade, and this helped them survive the famine in the 1990s by advancing in the border trade. Though legalisation of this trade was permitted only in the border areas, merchants from inner cities came to the border cities and brought China-manufactured consumer goods inland, subsequently leading to the emergence of underground trade and market networks across North Korea.

20 Ch’a Munsŏk, 'Konan ŭi haenggun gwa pukhan kyŏngje ŭi sŏnggyŏk pyŏnhwa', Hyŏntaepukhanyŏnku 8, no. 1 (2005): 43.

21 Ch'oe and Ku, 'Pukhan ŭi tosi 'jangmadang' hwalsŏnghwa ŭi tonghak', 166-7.

22 Yi Sŏnu, 'Sŏnkunchŏngch'iwa pukhansik kyŏngchekaehyŏk' [Military First Policy and North Korean Style Economic Reform], Hyŏntaepukhanyŏnku 12, no. 1 (2009): 140; Ch'oe Pong-dae and Ku Kap-u, 'Pukhan tosi nongminsichang hyŏngsŏng kwachŏngŭi ihaenglonchŏk hamŭi: 1950-1980nyŏntae sinŭichu, ch'ŏngchin, hyesanŭi sarerŭl chungsimŭro' [Formation Process of Farmers' Markets in North Korean Cities: in the Cases of Sinŭichu, Ch’ŏngchin, Hyesan, 1950-1980], Hyŏntaepukhanyŏnku 6, no. 2 (2003): 172.

23 Andrew Natsios, The Great North Korean Famine (Washington DC: Institute of Peace Press, 2001), 100.

24 Ch'oe and Ku, 'Pukhan ŭi tosi 'jangmadang' hwalsŏnghwa ŭi tonghak', 170. 
As the food situation deteriorated in the early 1990s, another important institutional change facilitated the spread of private economic activities; the Central Party delegated the responsibility to manage matters of livelihood to provincial authorities. By 1957, all residents except cooperative farmers (who were instead given an annual distribution from the harvest) had become entitled to food rations. ${ }^{25}$ Buying and selling of food was prohibited. Under this state-managed food distribution system, the moral consensus on the accessibility, availability and the price of food was essentially a relationship between the ruler (one ruler) and the rest. This consensus was withdrawn by the state in response to the food crisis. Kim Jong-il ordered city and county party and committees to resolve food matters on their own between 1992 and 1993. Between 1995 and 1996, state enterprises were also ordered to resolve their food situation on their own. ${ }^{26}$ City and county offices then allowed their residents to engage in market and border trades and private farming as a response to the decline and the eventual disappearance of the state rations. Farming and trade became morally justified and even necessary for people as they endured the hardship of the non-ration period and struggled to survive on their own. By promoting the slogan 'the Arduous March', from the beginning of 1996, thereby recalling the country's historical memory of guerrilla fighting in Manchuria in the colonial era, the state Party demanded of the people a spirit of endurance, perseverance and revolution. The state conducted internal war mobilisation against the external enemy and, by doing so, the sense of expectation that the state ensures food security was no longer held during the height of the famine.

During the Arduous March period, the state tried to maintain its control over the people while reluctantly turning a blind eye to market and other private economic activities. During the height of the famine, propaganda vans with loudspeakers continued to make pronouncements not to engage in anti-socialist activities. ${ }^{27}$ The heads of household, officials, health workers and teachers were obligated to remain in their workplace during the Arduous March, although all tried to negotiate with the state authorities to obtain time to devote to their families' survival by conducting difficult private economic activities in the form of

25 Kim Yang-hui, 'Ch'echeyujirŭl wihan pukhanŭi sikryangchŏngch'i' [North Korea’s Food Politics for Regime Maintenance], T’ongilmuncheyŏnku, 16.

26 Yang Mun-su, Pukhan ŭi kyehoekkyŏngje wa sijanghwa hyŏnsang [North Korea's Planned Economy and Marketisation Phenomenon] (Seoul: Institute for Unification Education, 2013), 30.

27 Lee Young-ok, interview by author, Seoul, 23 October 2013. 
farming and trade. By declaring the ideologically infused struggle against hardship over in 1998, the state reinvigorated its control over non-legal economic activities. In February 1999, Kim Jong-il attempted to shut all marketplaces and exhorted people to return to factories. ${ }^{28}$ The reimposition of control occurred through the creation of special groups to inspect and enforce the eradication of anti-socialist activities and conducting antimarket campaigns. Having already seen the spread of markets and the weakening of the ideology's effectiveness as a tool of social control, Kim Jong-il tried to constrain the market through 'regulatory harassment', creating 'economic police', and increasing the role of the military in social control and surveillance. ${ }^{29}$ Eventually, by the time of the 1 July 2002 reform, the state normalised the operations of major marketplaces and made price adjustments. This reform path was reversed from August 2005 with counter-reforms banning grain trade and some other businesses and resumption of the public distribution system. In subsequent years, the counter-reform path was reinvigorated through new restrictions on the farming of private plots, the imposition of age and item restrictions on market trades, and crackdowns on corruption. ${ }^{30}$

Despite the state's swing between reform and counter-reform, the marketisation process that began during the Arduous March period was never effectively reversed. Haggard and Noland's 2012 report of survey data of North Korean refugees collected in both South Korea and China demonstrates that neither reforms nor retrenchments had much impact on the significance of the market in household economy, and this reflects the state's incapacity to control the marketisation process. ${ }^{31}$ Today, the market has become the most vital and central part of life in North Korea. It has gradually pushed the state to adopt the market as a fact of life. The market has eroded the state.

28 Ch'a, 'Konan ŭi haenggun gwa', 57.

29 Natsios, The Great North Korean Famine, 100; Yi, 'Sŏn'gunjŏngch'i wa pukhansik kyŏngjegyehyŏk', 145.

30 Stephan Haggard and Marcus Noland, Witness to Transformation: Refugee Insights into North Korea, (Washington DC: Peterson Institute for International Economics, 2011), 9.

31 ibid., 79. 


\section{Mechanisms for the Emergence and the Spread of the Market-Cooperation and Conflict among Officials and Non-Officials}

Let us look more closely at this process of erosion as it takes place in everyday life. A common pathway is to start by engaging in petty trade by selling what one can in pursuit of one's own survival. Selling off existing marketable items from home to secure seed money for petty trade or simply to buy grains or medicine for the family was a desperate strategy for survival during the period when state rations were non-existent. Among the lowest strata of market traders, people buy flour to make bread and sell it at the edge of the marketplace. Prohibited items, most commonly alcohol, are sold at home quietly to neighbours. A much more physically demanding form of trade is itinerant trading. The long-distance bartering of certain foods and manufactured goods between urban and rural areas, between coastal or inland cities and border cities, or across the North Korea-China border is an unimaginably arduous but nevertheless widespread practice. Though these petty traders do not have sophisticated management skills and structures, trading in North Korea essentially demands some level of entrepreneurial skill because of various barriers imposed on the traders. As capital accumulates, petty traders move on to more profitable items and trading that demand more sophisticated ways of managing and building relationships, acquiring modes of transportation, procuring resources, and accessing the market.

Those who started as petty traders often make enough money to obtain official connections to make their businesses more profitable and secure. Individual traders, in the course of trading, make a shift in the items and modes of exchange and in the relationships they develop to facilitate their trade activities so as to earn more profit and obtain a secure source of income. Most trade activities develop as the result of collaboration and mutual dependency between officials and marketeers. The bribery relationship develops either through the initiative of the officials who are responsible for implementing laws against market activities, or through the initiative of residents who want to embark on non-legal activities under conditions of uncertainty. Thus, the more entrepreneurial one becomes, the more risks one has to take, and the more dependent one's business becomes on individuals in the state apparatus, in the absence of market-facilitating and market-protecting institutions. The larger the 
scale of trade, the more essential it is to establish official connections, often with multiple law enforcement authorities. As a result, privately run businesses in North Korea almost always form state agency affiliations and the businesses make payoffs to relevant government agencies. ${ }^{32}$ State officials often initiate the process of developing enterprises, using their status and connections to access state resources and information. In other words, one's access to material and social resources depends on access to power.

The division between officials (kanbu) and non-officials in North Korea was clear even before the 1990s crisis. This was because the division aligned with one's songbun, the social stratification category based on family background. Of the three main categories, 'core', 'wavering' and 'hostile', only those who belong to the core class could qualify to fill official positions that are considered important in the state apparatus. Wavering class members of various sorts could become kanbu only when the individuals faithfully proved their loyalty to the Party. The songbun division, which is passed on from generation to generation, clearly reinforced the division between officials and non-officials, and the discrimination and resentment were clearly recognised and internalised. Yet, because of North Korea's centrally controlled ration and wage system, as well as the egalitarianism embedded in its communist ideology, the division had never been a socioeconomic one. Only after the 1990s did the political-social cleavage became an economic and contentious one. ${ }^{33}$

Officials in North Korea constitute those who hold various offices in the state apparatus. Refugee informants say that in an ordinary rural city or town, around 10 per cent of the town are officials of various sorts. ${ }^{34}$ The number of kanbu had expanded since the postwar period in the 1950s as the state's policy increased the number to implement its postwar reconstruction policies and consolidate the state power through entrenchment and mobilisation. With the decline of the state-planned economy and the emerging vitality of farmers' markets, corruption of the $k a n b u$ was already growing by the early 1990s. When the ration system

32 On such dynamics of state-business relations, see Andrei Lankov, 'Limits to Marketisation: State and Private in Kimist North Korea', Sino NK, 14 June 2013, sinonk.com/2013/06/14/marketizationand-its-limits-state-private-enterprises-in-north-korea/.

33 Adopted from Hahn Soon-young, interview by author, Suwon, 15 May 2015.

34 It is estimated that the core class constituted 28 per cent of the population in the mid-1990s and the Korean Workers' Party membership as high as 15 per cent of the population: Haggard and Noland, Witness to Transformation, 55. 
collapsed, officials and their families, exploiting their access to state resources, diverted food, stripped enterprise assets, and conducted various forms of trade. ${ }^{35}$ Officials who belonged to various law enforcement agencies were given incentives to remain loyal to the state through the provision of rations. ${ }^{36}$ Regulations became beneficial to them, in the sense that they could take bribes using their authority to turn a blind eye to those who flouted the regulations. ${ }^{37}$ Under Kim Jong-il and Kim Jong-un, law enforcement officials and the army have become the most powerful actors. Law enforcement officials are today referred to as 'those who hold the swords'. ${ }^{38}$

Despite the clear differentiation that developed between officials and non-officials, collaboration occurs extensively. At the local level, the majority of state officials, including those in the lower levels of the legal apparatus, are poor. One informant said, 'if the town's people are poor, so are the officials of the town'. ${ }^{39}$ The continued existence of regulations against market activities provides the officials continued opportunities for bribery. Law enforcement officials foresee a greater long-term benefit from collaboration with those who ignore the regulations than from implementation of legal punishments against marketeers. It is also a matter of survival. Because officials are prohibited from conducting market activities, only in collusion with marketeers can they maintain their livelihoods. The collaborative relationship becomes widespread and normalised.

This collaboration in stealing state resources brought about a hollowingout of the state-planned economy. The widespread stealing in North Korea since the 1990s is not only a result but also a constituting phenomenon of the hollowing-out of the state. Since the supply of resources and electricity virtually stopped even to top priority national enterprises at some points in the 1990s, workers and guards, out of desperation in the absence of the state rations and wages, began pilfering parts of idle factory facilities. Stealing occurred rather quietly at all levels of the society: opportunistic large-scale stealing by officials in managerial positions and small-scale

36 Kim Sung-Chull (1997), 'Pukhan kanbujŏngch'aek ŭi jisok kwa byŏnhwa' [Continuities and Changes in North Korea's 'Policy of Cultivating Officials'], Korea Institute for National Unification,

37 Cha Kyungsook, interview by author, Seoul, 13 May 2015.

38 Choi Seungmin, interview by author, Seoul, 13 May 2015.

39 Ahn Chong-han, interview by author, Seoul, 6 June 2015. 
pilfering by ordinary labourers and farmers occurring simultaneously and in collaboration. In this way, this state hollowing-out occurred quietly without the violent outbreaks of contention between the state and the people trying to survive.

What resulted from this collaboration between the officials and nonofficials through bribery is the institutionalisation of illegal private economic practices. Pilfering, for example, has become so widespread that it is considered a common and morally acceptable practice despite the state's repressive control against it through the terror of imprisonment and ad hoc public execution. Refugee informants describe the act of stealing as 'deducting' or 'taking a part' of a public asset. ${ }^{40}$ Stealing and the collusive relations through which stealing occurs are regularised and systematised. Ways of diverting state resources by selling them in a market become institutionalised. Often these informally systematised practices demonstrate similar patterns across different institutions, i.e. state enterprises, cooperative farms, schools and hospitals.

\section{The Role of Communal Culture}

The collaboration between local officials and marketeers does not only depend on bribery and the sharing of profits. A cultural factor, traditionalism, also contributes to the formation of corrupt relationships and shaping the officials' orientation to long-term benefit. The culture of close personal relationships facilitates the formation of collaboration. The personal connections include family and acquaintances as well as new relationships formed for the sake of convenience and mutual benefit. Women who became successful marketeers 'buy' official positions in the state apparatus for their husbands by 'paying for' their higher education in order to create potential for their career advancement. Marital relationships thus become a space where a marriage between the market and the state occurs. ${ }^{41}$ It is often the wives of officials who conduct largerscale trade activities because they are given a greater level of protection in conducting non-legal activities. Often State Security officers are school

40 Kim Bun-nyu, interview by author, Seoul, 6 June 2015.

41 Park Hwa-sook, interview by author, Seoul, 20 December 2013. 
friends or family members. Depending on the circumstances, personal affection and friendship overcome the official obligation to implement rules, especially when material benefits follow. ${ }^{42}$

The North Korean regime has fostered a culture of a family state in which constituent members of society care for one another like family members. The culture of the family state has facilitated the development and sustenance of smuggling in the border regions. Collaborative relationships formed between border control officials and female marketeers in Hyesan are facilitated by filial sentiments between son-like border control guards and motherly marketeers. Since the Arduous March period, 'mothers' have become the dominant agents of smuggling, collecting all kinds of available goods ranging from medicinal herbs to metal scraps. Border control officials are young males of their sons' age. This collaboration between the young border control officials and middle-aged women helped the border smuggling to continue in Hyesan. ${ }^{43}$ The culture of the family state not only had the effect of strengthening the bond between the leader and the people but also of engendering filial respect and motherly care outside of the nuclear family. ${ }^{44}$

The culture of close communal and interpersonal relationships nullifies the highly complicated ad hoc regulations of the Centre. One effect of the existence of multiple layers of enforcement agencies is that all become complicit. For instance, a refugee informant from North Hamkyung Province recounted that she had to bribe ' 10 strong individuals' to safely conduct her trade business in North Hamkyung Province. ${ }^{45}$ Individuals cannot own automobiles, thus to conduct long-distance trade using a motor vehicle, one has to borrow the vehicle from a state enterprise for a cost. But pay-offs themselves do not guarantee protection from possibly being subjected to regulations by law enforcement agencies. To protect oneself and one's business, one has to build connections with powerful individuals, including three security authorities - the Public Security, the State Security, the Army Security - as well as other authorities such as North Korean Democratic Youth League officials, the Party cell official and the prosecutor. All become complicit. For a retired army officer who

42 Kang Seung, interview by author, Incheon, 10 December 2013; Ahn Chong-han, interview by author, Seoul, 6 June 2015.

43 Lee Ki-wol, interview by author, Suwon, 15 May 2015.

44 On an anthropology of the family state, see Heonik Kwon and Byung-Ho Chung, North Korea: Beyond Charismatic Politics (Rowman and Littlefield Publishers Inc., 2012), 18-33.

45 Park Kyung-sook, interview by author, Seoul, 5 May 2015. 
conducted illegal border smuggling through his connections with multiple legal authorities, his response to the news of a special inspection force coming down to his town was to defect. By disappearing, he could save all the officials who were involved. ${ }^{46}$ Thanks to these adaptive strategies developed at the local level, the Centre's enforcement strategies have not worked effectively. There is a popular saying, 'the Centre's policy does not last more than three days'. ${ }^{47}$

\section{The Development of Contention within Hegemony}

Refugee informants justify their private economic activities in terms of the hegemonic ideology of self-reliance. Under this encompassing ideology of self-reliance, North Korean people gradually negotiated their private use of time, space and labour away from extensively collective ways of life. North Korea first used the slogan of self-reliance in the early 1960s when the Sino-Soviet dispute and a resultant decline of aid from both allies jeopardised the first Five Year Economic Plan (1957-61). Selfreliance was not a motto invented by the North Korean regime. It was in fact China's guiding policy around the 1960s. ${ }^{48}$ The slogan had a dual usage. For the nation as a whole, it delineated North Korea's basic principle of national economic reconstruction as an autonomous process with little dependence on aid from its allies. The slogan was reinforced as the economy deteriorated and when the regime took a counter-reform isolationist path since the mid-2000s. ${ }^{49}$

Internally, the slogan mobilised people to proactively seek ways to contribute to national economic development and socialist revolution. As observed by Suzy Kim, this theme of the individual as a proactive agent of revolution is consistent from the beginning of North Korea's socialist revolution in $1945 .{ }^{50}$ Cheehyung Kim's work on Chuch'e Sasang (the ideology of self-reliance) elaborates this dynamic of the socialist economy's essential dependence on the workers' spontaneous innovations

46 Ahn Chong-han, interview by author, Seoul, 6 June 2015.

47 Kim Mirae, interview by author, Seoul, 15 May 2015.

48 Lankov, The Real North Korea, 72.

49 Cho Tongho, 'Kidae wa bigwansog ŭi charyŏkkaengsaeng chŏnryak' [Strategy of Self-Reliance in Hope and Despair], Kukkachŏnryak 14, no. 2 (2008): 87-114.

50 Kim, Everyday Life in the North Korean Revolution. 
and labour heroism. Through an analysis of literary works of the 1970s, Kim concludes: 'the moments when the North Korean people are assumed to be under the greatest control may actually be the moments of agency'. ${ }^{51}$ The flip-side of this dynamic of ownership and totality is that individual ownership of the revolution is entirely subject to the totality of the state. Individual ownership and creativity existed in essence for the cause of the nation as a whole.

The value of labour, diligence and self-reliance involve paternalistic thinking. Changsa (selling goods or trading) for the majority of the population had initially developed only to the extent of earning residual income through the making of bread or noodles out of flour and selling them in the marketplace. Conducting market trade, if performed to an unnoticeable and unexceptional degree, is regarded as a self-reliant effort to survive on one's own in times of hardship, and therefore does not contradict the official ideology. An informant describing everyday life in North Korea reflects in her narratives what is seemingly the state-guided discourse on the value of labour: 'the harder your physical body works, the stronger your mental facilities become. There is neither dementia nor cancer in North Korea. ${ }^{52}$ Private economic activities of trade and farming, in aggregate, echo the themes of collective labour, diligence and self-reliance that have long been promoted throughout the history of the country. While factories and cooperative farms are emptied out in the absence of resources, labour takes place in houses, marketplaces and in the mountains. In fact, ordinary-scale market trades and private farming are so widespread that even those who had other unconventional and non-legal sources of income conduct these activities to hide such illicit sources. One elderly refugee informant told me that while she had no need to do changsa nor farming because her daughter who had defected to South Korea was sending her money, she engaged in both activities on a daily basis in order to disguise her other source of income and pretend that it was her sole source of survival. Changsa was justified as a self-reliant coping strategy and was even promoted through peer-pressure as a form of diligence. Many informants said that those who did not engage in either

51 Kim Cheehyung, 'Total, Thus Broken: Chuch'e Sasang and North Korea's Terrain of Subjectivity', Journal of Korean Studies 17 (2012).

52 Park Hwa-sook, interview by author, Seoul, 20 December 2013. 
changsa or farming were lazy people. Fahy observes from the narratives of defectors, 'the proper response was not depression or melancholia but action' ${ }^{53}$

People strategically negotiated and acquired a greater right to conduct trade activities by distancing themselves from politics. One way to distance oneself from politics is to use one's social identity position. As we have seen, the North Korean state imposes the songbun system, which stratifies the entire population into categories based on family lineage background and differentiated people's access and possibilities for political careers. In return, however, officials were more restricted in conducting private economic activities than non-officials. Conversely, the more marginal one's position is in the system, the greater freedom one has. While minorities, for example, Chinese residents in North Korea and ethnic Koreans from Japan who migrated to North Korea (mostly in the 1960s) have been from time to time subject to political purges, these groups have also been selectively allowed a greater level of economic freedom, and allowed to utilise their economic resources and connections abroad to supply goods necessary, useful and desirable to officials.

For instance, returnees from Japan gained an entitlement to greater freedom in conducting market activities. Those who 'returned' from Japan faced much discrimination in the system; having come from a capitalist world, they were closely watched, often scapegoated and many perished in political prisons. While readily integrated into local communities in everyday life through work and education, they were excluded from certain duties as well as rights. Returnees or children from a returnee family in general could not expect to advance far in a political career, though exceptions existed. As a result, many pursued careers in professions such as medicine. Interestingly, they were also given a greater level of leniency in conducting non-legal activities such as trading. To borrow the words of one interviewee, 'we had more freedom in economic activities as long as we did not do anything political'. Some lived off luxury goods and money sent from their relatives, and the demand for the luxury goods came from local officials. Some returnees had household businesses, selling secondhand clothes and electronics smuggled in from Japan long before the economic crisis in the 1990s, and such businesses only increased with

53 Sandra Fahy, Marching through Suffering: Loss and Survival in North Korea (New York: Columbia University Press, 2014), 51. 
the crisis. ${ }^{54}$ When rations stopped, these groups of individuals conducted trade activities using their connections abroad, while supplying payments to law enforcement officials.

The logic of the freedom of marginalisation applies within the household too. The heads of households were obligated to remain in the workplace. Thus, it was the elderly and married women who first explored the possibilities of private economic activities, because they had a greater capacity to evade labour mobilisation by the state, and to use their time in their own way. This flexibility in carving out time and labour away from collective uses differs according to enterprise and agency units, regions and time periods. ${ }^{55}$

Active resistance often took place on the streets at the local level. This often involved fierce protest in the form of continuing market trade. In smaller towns, markets were kept open as a result of ongoing resistance by women. Eventually, designated market places opened. The hometown of one refugee informant had less than 1,000 households, and thus was excluded from permission to open up the marketplace. Residents protested to local officials, 'don't you have to allow us simply to live?' In May 2004 everyone went out to the streets spontaneously and formed an informal marketplace with their items on the street. It looked as though the authority would soon crush the protest, but they did not dare to do so. The county officials then ran around in efforts to persuade higher administrative levels to authorise the market. In my refugee informant's words, because the state could not provide for the people, it eventually had to permit market trade with a state-controllable boundary. ${ }^{56}$

There is a moral dimension to the fact that petty traders are often left to their own devices. There are implicit norms about the way the laws should be enforced. The norms depend on the scale of trade. A refugee informant said, 'there is no justification for enforcing the law upon petty traders. They are not afraid of dying'. Only when businesses become visibly significant in size do security officials appear and demand bribes. Small traders are left to grow bigger. ${ }^{57}$ The perception that there is no justification for suppressing petty trade indicates that there is a certain

54 Kang Seung, interview by author, Incheon, 10 December 2013; Kim Taekyun, interview by author, Incheon, 10 December 2013.

55 Lee Young-ok, interview by author, Seoul, 23 October 2013.

56 Han Soon-young, interview by author, Suwon, 15 May 2015.

57 Park Kyung-sook, interview by author, Seoul, 5 May 2015. 
shared moral consensus about leaving these petty trades unregulated. An informant metaphorically remarked, 'a backpack becomes a hand cart and a hand cart becomes an ox cart, and an ox cart becomes an automobile. Then the trader has to start worrying about potential risks of confiscation. ${ }^{58}$ Trading on a significant scale becomes a risky and nerveracking experience. The richer one becomes, the more regulations one risks violating and the more bribes one has to pay.

\section{Conclusion}

Marketisation in North Korea is a bottom-up phenomenon that occurred under the continued regulation of market trade activities. Market trade emerged as a survival strategy in the absence of state rations, and quietly but rapidly encroached on the state sector economy. The hollowing-out of the centralised planned economy was not only a result of the greater structural change of the end of the Cold War but also of a redistribution of social goods and attainment of autonomy achieved by people's everyday moves to conduct market trade for the simple purpose of survival.

The few attempts by the state to re-control and suppress the market force since 2005 have ended in failure. Since Kim Jong-un came to power in 2012, such efforts ceased due to the state's perceived fear of unsettling of people if market trades are restricted and oppressed. The market has become the way of life in North Korea. Demands for private economic spaces existed prior to the economic crisis. Under the guise of collectivism as the only way of life, people quietly conducted very small-scale private economic activities as a means of acquiring minimal subsistence security for their household. As the crisis deepened, the activities expanded rapidly in scale and number despite the state's continued efforts to control such bottom-up movements. This indicates that even a totalitarian state like North Korea does not have total control of the society.

Shared interests, communal culture and a collective sense of morality all become important factors contributing to the emergence of the market. Private space is demanded and is actively negotiated from continued imposition of the collective. But in the narratives of refugee informants, private economic activities are also justified as collective self-reliance actions. Continuities and changes in the North Korean state-society

58 Park Hwa-sook, interview by author, Seoul, 20 December 2013. 
relations in everyday life spaces occur in the precarious balance between the collective management of hardship, group demands for private spaces and resources, and collaborative and contentious relations between officials and non-officials.

What is striking about the emergence and expansion of market in North Korea is the sheer scale and significance it has attained today. As much as the North Korean state building was a process of collective mass mobilisation, the people's resort to the market put an end to the revival of the state-planned economic system. This demonstrates that the totalitarian state depends on the compliance of people. The North Korean people have turned the totalitarian system upside-down. Marketisation in North Korea demonstrates the agency of ordinary people even in the total absence of institutionally guaranteed economic freedom and even under the presence of control by fear and terror implemented through selective punishment. To this extent, the authorities indeed are the prisoners of people'. ${ }^{59}$

\section{Acknowledgements}

I would like to thank Tessa Morris-Suzuki and Jong-Sung You for their valuable comments.

59 E. P. Thompson, 'The Moral Economy of the English Crowd in the Eighteenth Century', Past and Present 50 (1971): 79. 
This text is taken from New Worlds from Below: Informal life politics and grassroots action in twenty-first-century Northeast Asia, edited by Tessa Morris-Suzuki and Eun Jeong Soh, published 2017 by ANU Press, The Australian National University, Canberra, Australia. 